Check for updates

Cite this: RSC Adv., 2020, 10, 36843

Received 29th July 2020

Accepted 30th September 2020

DOI: $10.1039 / \mathrm{dOra06555b}$

rsc.li/rsc-advances

\title{
The radical scavenging activity of moracins: theoretical insights $\uparrow$
}

\begin{abstract}
Quan V. Vo (D)*ab and Nguyen Thi Hoa*b
Moracins are natural products that have been isolated from different plants such as Artocarpus heterophyllus, Cassia fistula, Morus alba, and Morus mesozygia. Studies showed that moracins may have various advantageous physiological effects such as anticancer, anti-inflammatory, anticholinesterase and particularly antioxidant activities. Most of these bioactivities have not been studied systematically. In this study, the radical scavenging of a typical moracin (moracin $\mathrm{M}, \mathrm{MM}$ ) against $\mathrm{HO}{ }^{\circ}$ and $\mathrm{HOO}$ radicals was evaluated by thermodynamic and kinetic calculations in the gas phase as well as in water and pentyl ethanoate solvents. It was found that the overall rate constants for the $\mathrm{HO}^{*}$ radical scavenging in the gas phase and the physiological environments are in the range of $10^{11}$ to $10^{10} \mathrm{M}^{-1} \mathrm{~s}^{-1}$, respectively. For the $\mathrm{HOO}^{\circ}+\mathrm{MM}$ reaction the rate constants are $4.10 \times 10^{7}$ and $3.80 \times 10^{4} \mathrm{M}^{-1} \mathrm{~s}^{-1}$ in the polar and lipid media, respectively. It is important to notice that the single electron transfer pathway of the anion state $\left(\mathrm{MM}^{-} \mathrm{O}^{\prime-}\right)$ dominated the $\mathrm{HOO}^{*}$ radical scavenging in the aqueous solution, whereas in lipid medium the neutral MM exerted its activity by the formal hydrogen transfer mechanism. The HOO' radical scavenging of $\mathrm{MM}$ is comparable to that of Trolox in lipid medium, whereas it is 315.4 times more active in the polar environment.
\end{abstract}

\section{Introduction}

The moracin family of natural product is based on a benzofuran heterocycle. There are about 24 natural moracins ${ }^{1}$ that have been isolated from a range of different plants such as Artocarpus heterophyllus, ${ }^{2}$ Cassia fistula, ${ }^{3}$ Morus alba ${ }^{4-7}$ and Morus mesozygia. ${ }^{\mathbf{8} 9}$ Studies showed that moracins can exert antiaromatase,${ }^{10}$ anticancer, ${ }^{11}$ antidiabetes, ${ }^{12}$ anti-inflammatory, ${ }^{13}$ anticholinesterase, ${ }^{14}$ antifungal ${ }^{15}$ and antioxidant ${ }^{9,16-18}$ activities. The experimental data indicated that moracins have potent antioxidant activity. ${ }^{1}$ Moracins $\mathrm{R}, \mathrm{T}$ and $\mathrm{U}$ showed good activity in 2,4-dinitrophenyl-1-picrylhydrazyl (DPPH) assays in methanol. ${ }^{9}$ Moracin $\mathrm{C}$ exerted high inhibitory activity in lipid peroxidase and free radical scavenging assays. ${ }^{17,19}$ Moracins $\mathrm{M}$ and $\mathrm{N}$ showed moderate free radical scavenging activity in inhibition of blue formazan formation and reduced the UV. ${ }^{20}$ In terms of theoretical studies, the antioxidant activity of moracin $\mathrm{T}$ was evaluated, ${ }^{21}$ however the research was limited to thermodynamic calculations. Kinetic analysis (i.e. calculating rate constants for the radical scavenging) is a more accurate way to predict activity and the effects of solvents, particularly the physiological environments, warranting further study.

${ }^{a}$ Institute of Research and Development, Duy Tan University, Danang 550000 Vietnam. E-mail:vovanquan2@duytan.edu.vn

${ }^{b}$ The University of Danang - University of Technology and Education, 48 Cao Thang, Danang 550000, Vietnam.E-mail:vvquan@ute.udn.vn; ngthoa@ute.udn.vn

$\uparrow$ Electronic supplementary information (ESI) available. See DOI: 10.1039/d0ra06555b
The moracin structures are based on the benzofuran heterocycle (Fig. 1), in which the hydroxyl group mostly presents at C3, C5 and C6' positions. Studies showed that the phenolic groups play a decisive role in the antioxidant activity of aromatic compounds. $^{22-27}$ Moracin M (MM, Fig. 1) ${ }^{28}$ is a typical compound of the family since this compound contains HO groups in all of the typical positions but without any substituents. Considering that theoretical study on antioxidant activity of all of natural moracins is a difficult task due to the large structures and numerous compounds, in this study MM was used as a referenced compound for evaluating the antioxidant activity of moracins to save calculating time but still obtain reliable and accurate results.

Therefore, this study aims to investigate the radical scavenging activity of $\mathrm{MM}^{\mathrm{N}}$ against $\mathrm{HO}^{\circ}$ and $\mathrm{HOO}^{\circ}$ radicals in the gas phase, as well as aqueous and lipid media using thermodynamic and kinetic calculations. The favored antioxidant mechanism of MM specific to each reactive oxygen species, chemical environments and moracin structures is also evaluated.

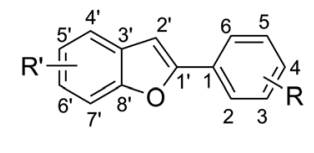

moracin structures

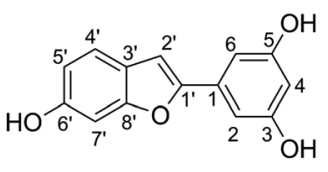

moracin $\mathrm{M}$
Fig. 1 The generic structure of moracins and the structure of moracin $M(M M)$. 


\section{Computational methods}

In this study, the quantum mechanics based test for overall free radical scavenging activity (QM-ORSA) protocol with the solvation model density (SMD) method (for water and pentyl ethanoate solvents) were used to performed the kinetic calculations. $^{22,29-34}$ The rate constant $(k)$ was calculated by using the conventional transition state theory (TST) (at 298.15 K, 1 M standard state) according to the eqn (1) (details method in Table $\mathrm{S} 1, \mathrm{SI} \dagger):^{35-40}$

$$
k=\sigma \kappa \frac{k_{\mathrm{B}} T}{h} \mathrm{e}^{-\left(\Delta G^{\neq}\right) / R T}
$$

where: $\sigma$ is the reaction symmetry number, ${ }^{\mathbf{4 1 , 4 2}} \kappa$ contains the tunneling corrections calculated using the Eckart barrier, ${ }^{43} k_{\mathrm{B}}$ is the Boltzmann constant, $h$ is the Planck constant, $\Delta G^{\neq}$is the Gibbs free energy of activation.

All calculations were carried out using Gaussian 09 software $^{44}$ at the M06-2X/6-311++G(d,p) level of theory. ${ }^{24,45,46}$

\section{Results and discussions}

\subsection{The radical scavenging in the gas phase}

3.1.1. Thermodynamic study. Previous studies showed that the antioxidant activity could take place following either of three typical pathways including formal hydrogen transfer (FHT), sequential electron transfer proton transfer (SETPT), and sequential proton loss electron transfer (SPLET) mechanisms. From the thermodynamic point of view they can be characterized by the energetics of the respective first step of the mechanism, i.e. the bond dissociation enthalpy (BDE), ionization energy (IE) and proton affinity (PA) for FHT, SETPT and SPLET, respectively. ${ }^{23,25}$ Thus as an initial step, the thermochemical parameters of $\mathrm{MM}$ were calculated in the gas phase and are presented in the Table 1 . The lowest calculated BDE and PA values were observed at the $\mathrm{O6}^{\prime}-\mathrm{H}$ bond at 83.3 and $336.6 \mathrm{kcal} \mathrm{mol}^{-1}$, respectively. The values of these parameters for $\mathrm{O} 3(5)-\mathrm{H}$ bonds were higher than that of the $\mathrm{O}^{\prime}-\mathrm{H}$ bond by about $25 \mathrm{kcal} \mathrm{mol}^{-1}$ for BDEs and $4 \mathrm{kcal} \mathrm{mol}^{-1}$ for PAs. Thus it suggests that the antioxidant activity of MM according to FHT and SPLET mechanisms is dominated by the $\mathrm{O6}^{\prime}-\mathrm{H}$ bond. However, the antiradical activity of MM following the SETPT or SPLET would be difficult due to the high IE and PA values (IE = $170.9 \mathrm{kcal} \mathrm{mol}^{-1}, \mathrm{PA}=336.6-340.2 \mathrm{kcal} \mathrm{mol}^{-1}$ ), compared with the BDE values. Thus these antioxidant mechanisms were ignored in further study and the antioxidant activity of MM was only modelled by $\mathrm{H}$-abstraction at the $\mathrm{O6}^{\prime}-\mathrm{H}$ bond.

Table 1 The calculated BDEs, PAs and IEs (in kcal mol${ }^{-1}$ ) in the gas phase of MM

\begin{tabular}{lrll}
\hline Position & BDE & PA & IE \\
\hline O3-H & 108.3 & 340.2 & 170.9 \\
O5-H & 107.9 & 339.3 & \\
O6'-H & 83.3 & 336.6 &
\end{tabular}

As shown in previous studies, there is an additional pathway to consider, the radical adduct formation (RAF) mechanism plays an important role in the radical scavenging of several phenolic compounds, particularly in the $\mathrm{HO}^{\circ}$ antiradical activity. ${ }^{31,47-49}$ Thus, to gain further insights into the favored antioxidant pathways, the free energy $\left(\Delta G^{\mathrm{O}}\right)$ for the $\mathrm{HO}^{\circ}$ and $\mathrm{HOO}^{\circ}$ radicals scavenging of the $\mathrm{MM}$ in the gas phase following the FHT and RAF mechanisms were computed and are shown in Table 2. It was found that the $\mathrm{HO}^{*}$ radical scavenging reactions are spontaneous $\left(\Delta G^{\mathrm{o}}<0\right)$ for all positions in MM, apart from the RAF at the $\mathrm{C}^{\prime}{ }^{\prime}$ position $\left(\Delta G^{\mathrm{o}}=3.5 \mathrm{kcal} \mathrm{mol}^{-1}\right)$, whereas the $\mathrm{HOO}^{*}$ radical scavenging is only spontaneous at the $\mathrm{O}^{\prime}-\mathrm{H}$ bond $\left(\Delta G^{\mathrm{o}}=-2.0 \mathrm{kcal} \mathrm{mol}^{-1}\right)$ according to the FHT mechanism. Hence, the kinetic evaluation for the radical scavenging of $\mathrm{MM}$ against the $\mathrm{HO}^{\circ}$ radical in vacuum was performed at all of positions $\left(\Delta G^{\mathrm{O}}<0\right)$, while that for the $\mathrm{HOO}^{\circ}$ radical scavenging was only calculated for the $\mathrm{H}$-abstraction of the $\mathrm{O6}^{\prime}-\mathrm{H}$ bond.

3.1.2. Kinetic study. Kinetic study of the $\mathrm{HO}^{\circ}$ and $\mathrm{HOO}^{\circ}$ scavenging activity of $\mathrm{MM}$ in the gas phase was performed following the (QM-ORSA) protocol, ${ }^{30,33,34}$ and the kinetic parameters are presented in Table 3.

As shown in Table 3, the $\mathrm{HO}^{\circ}$ antiradical activity was dominated by the reactions at positions $\mathrm{C} 2, \mathrm{C} 6, \mathrm{C} 2{ }^{\prime}$ and $\mathrm{C}^{\prime}{ }^{\prime}$ for the RAF mechanism and the $\mathrm{O6}^{\prime}-\mathrm{H}$ bond for the FHT pathway as stated before. Thus the potential energy surfaces (PES) for these positions were also calculated and the results are shown in Fig. 2, whereas the optimized transition state (TS) structures and the density surfaces of the TSs and radicals are shown in Fig. 3 and $\mathrm{S} 1, \dagger$ respectively. Fig. 2 shows that the $\mathrm{H}$-abstraction of $\mathrm{O6}^{\prime}-\mathrm{H}$ bond follows a typical radial reaction: ${ }^{23,25}$ reactant $(\mathrm{R})$ $\rightarrow$ pre-complex (RC) $\rightarrow$ transition state (TS) $\rightarrow$ post-complex $(\mathrm{PC}) \rightarrow$ product $(\mathrm{P})$ where the calculated reaction barrier (energy + ZPE) was $4.3 \mathrm{kcal} \mathrm{mol}^{-1}$, whereas for the RAF mechanism at the $\mathrm{C} 2, \mathrm{C} 6, \mathrm{C} 2{ }^{\prime}$ and $\mathrm{C}^{\prime}$ positions, the $\mathrm{PC}$ was not observed at the reaction line. The reaction barriers for RAF

Table 2 The calculated $\Delta G^{\circ}$ values (in $\mathrm{kcal} \mathrm{mol}^{-1}$ ) of the reactions of MM with $\mathrm{HO}^{\circ}$ and $\mathrm{HOO}^{\circ}$ following the $\mathrm{FHT}$ and RAF mechanisms in the gas phase

\begin{tabular}{|c|c|c|c|}
\hline \multirow[b]{2}{*}{ Mechanism } & \multirow[b]{2}{*}{ Position } & \multicolumn{2}{|l|}{$\Delta G^{\mathrm{o}}$} \\
\hline & & $\mathrm{OH}$ & $\mathrm{OOH}$ \\
\hline FHT & $\mathrm{O} 6^{\prime}$ & -33.3 & -2.0 \\
\hline \multirow[t]{14}{*}{ RAF } & $\mathrm{C} 1-\mathrm{OH}$ & -2.0 & 19.0 \\
\hline & $\mathrm{C} 2-\mathrm{OH}$ & -15.2 & 7.1 \\
\hline & C3-OH & -8.3 & 12.6 \\
\hline & $\mathrm{C} 4-\mathrm{OH}$ & -14.0 & 7.7 \\
\hline & C5-OH & -8.0 & 12.1 \\
\hline & C6-OH & -17.1 & 6.9 \\
\hline & $\mathrm{C}^{\prime}-\mathrm{OH}$ & -13.5 & 8.5 \\
\hline & $\mathrm{C} 2^{\prime}-\mathrm{OH}$ & -17.7 & 5.4 \\
\hline & $\mathrm{C}^{\prime}-\mathrm{OH}$ & 3.5 & 21.5 \\
\hline & $\mathrm{C}^{\prime}-\mathrm{OH}$ & -13.8 & 6.8 \\
\hline & $\mathrm{C}^{\prime}-\mathrm{OH}$ & -8.3 & 11.5 \\
\hline & $\mathrm{C}^{\prime}-\mathrm{OH}$ & -14.5 & 5.7 \\
\hline & $\mathrm{C}^{\prime}-\mathrm{OH}$ & -10.6 & 7.8 \\
\hline & $\mathrm{C}^{\prime}-\mathrm{OH}$ & -7.1 & 14.2 \\
\hline
\end{tabular}


Table 3 Calculated activation energies $\Delta G^{\neq}$( $\left.\mathrm{kcal} \mathrm{mol}^{-1}\right)$, tunneling corrections $(\kappa)$ and $k_{\mathrm{Eck}}\left(\mathrm{M}^{-1} \mathrm{~S}^{-1}\right)$ at $298.15 \mathrm{~K}$ in the gas phase for the $\mathrm{HO}^{\circ}$ and $\mathrm{HOO}^{\circ}$ scavenging of the MM

\begin{tabular}{|c|c|c|c|c|c|c|}
\hline \multirow{2}{*}{$\frac{\text { Radical }}{\mathrm{HO}^{\circ}}$} & \multicolumn{2}{|c|}{ Mechanism } & \multirow{2}{*}{$\frac{\Delta G^{\neq}}{4.0}$} & \multirow{2}{*}{$\frac{\kappa}{2.2}$} & \multirow{2}{*}{$\frac{k_{\mathrm{Eck}}}{1.69 \times 10^{10}}$} & \multirow{2}{*}{$\frac{\Gamma^{b}}{15.5}$} \\
\hline & FHT & $\mathrm{O}^{\prime}$ & & & & \\
\hline & RAF & $\mathrm{C} 1$ & 13.3 & 1.4 & $1.57 \times 10^{3}$ & 0.0 \\
\hline & & $\mathrm{C} 2$ & 3.8 & 1.0 & $1.14 \times 10^{10}$ & 10.5 \\
\hline & & $\mathrm{C} 3$ & 9.8 & 1.3 & $4.94 \times 10^{5}$ & 0.0 \\
\hline & & $\mathrm{C} 4$ & 6.9 & 1.2 & $6.63 \times 10^{7}$ & 0.1 \\
\hline & & C5 & 9.4 & 1.3 & $1.08 \times 10^{6}$ & 0.0 \\
\hline & & C6 & 2.8 & 1.0 & $5.90 \times 10^{10}$ & 54.4 \\
\hline & & $\mathrm{C} 1^{\prime}$ & 6.0 & 1.1 & $2.95 \times 10^{8}$ & 0.3 \\
\hline & & $\mathrm{C} 2^{\prime}$ & 3.6 & 1.1 & $1.63 \times 10^{10}$ & 15.0 \\
\hline & & $\mathrm{C} 4^{\prime}$ & 7.3 & 1.3 & $3.55 \times 10^{7}$ & 0.0 \\
\hline & & $\mathrm{C} 5^{\prime}$ & 4.4 & 1.1 & $4.04 \times 10^{9}$ & 3.7 \\
\hline & & $\mathrm{C} 6^{\prime}$ & 5.7 & 1.1 & $4.40 \times 10^{8}$ & 0.4 \\
\hline & & $\mathrm{C} 7^{\prime}$ & 8.0 & 1.2 & $1.02 \times 10^{7}$ & 0.0 \\
\hline & & $\mathrm{C} 8^{\prime}$ & 10.3 & 1.3 & $2.11 \times 10^{5}$ & 0.0 \\
\hline & $k_{\text {overa }}$ & & & & $1.08 \times 10^{11}$ & \\
\hline $\mathrm{HOO}^{\bullet}$ & FHT & O6 ${ }^{\prime}$ & 13.6 & 248.8 & $1.69 \times 10^{5}$ & 100.0 \\
\hline
\end{tabular}

pathway were in the range of 1.0 to $2.5 \mathrm{kcal} \mathrm{mol}^{-1}$. The lowest reaction barrier was observed at the RAF of $\mathrm{C} 6$ position $\left(1.0 \mathrm{kcal} \mathrm{mol}^{-1}\right)$. This suggests that the addition of $\mathrm{HO}^{\circ}$ radical at C6 plays a fundamental role in the hydroxyl radical scavenging of MM. In term of $\mathrm{HOO}^{\circ}$ radicals, the reaction barrier for the $\mathrm{H}$-abstraction of $\mathrm{O6}^{\prime}-\mathrm{H}$ bond was $12.5 \mathrm{kcal} \mathrm{mol}^{-1}$.

It was found that the overall rate constant $\left(k_{\text {overall }}\right)$ for the $\mathrm{HO}^{\circ}$ radical scavenging in the gas phase was $1.08 \times 10^{11} \mathrm{M}^{-1}$ $\mathrm{s}^{-1}$, whereas that for the $\mathrm{HOO}^{\circ}$ antiradical activity was $1.69 \times$ $10^{5} \mathrm{M}^{-1} \mathrm{~s}^{-1}$ (Table 3). The hydroxyl radical scavenging activity was defined by the RAF mechanism $\left(T>83 \%\right.$, at the C2, C6, C2 ${ }^{\prime}$ and $\mathrm{C}^{\prime}$ positions), in which the addition of $\mathrm{HO}^{\circ}$ into $\mathrm{C} 6$ position contributed about $54 \%$ in the $k_{\text {overall }}$. That is in good agreement with the obtained results at the PES analysis. The $\mathrm{H}$ abstraction of $\mathrm{O}^{\prime}-\mathrm{H}$ bond contributed $15.5 \%$ in the $k_{\text {overall }}$ of the $\mathrm{HO}^{\circ}$ radical scavenging, while that decided the $\mathrm{HOO}^{\circ}$ antiradical activity.

\subsection{The radical scavenging in the physiological environments}

3.2.1. Acid-base equilibria. To account for the effect of physiological environments, the radical scavenging of $\mathrm{MM}$ against $\mathrm{HO}^{\circ}$ and $\mathrm{HOO}^{\circ}$ radicals was modelled in water at $\mathrm{pH}=$ 7.4 for aqueous solution and in pentyl ethanoate for lipid medium. To determinate the state of $\mathrm{MM}$ in the aqueous solution at $\mathrm{pH}=7.4$, the acid-base equilibria of $\mathrm{MM}$ was calculated using the model reaction (2) and the eqn (3), given from literature. ${ }^{24,30,50}$

$$
\begin{gathered}
\mathrm{HA} \rightarrow \mathrm{A}^{-}+\mathrm{H}^{+} \\
\mathrm{p} K_{\mathrm{a}}^{\text {calc }}=m \Delta G_{\mathrm{BA}}^{\mathrm{o}}+C_{0}
\end{gathered}
$$

where $\Delta G_{\mathrm{BA}}^{\mathrm{o}}$ was obtained from the reaction (2) following the eqn (4); $m$ and $C_{0}$ are fitted parameters directly obtained from ref. 50 .

$$
\Delta G_{\mathrm{BA}}^{\mathrm{o}}=\Delta G_{\mathrm{A}^{-}}^{\mathrm{o}}-\Delta G_{\mathrm{HA}}^{\mathrm{o}}
$$

As expected, the lowest PA value was calculated at $\mathrm{O6}^{\prime}-\mathrm{H}$ bond (Table 1). Thus this group was used to investigate the acid-base equilibria of MM. The calculated $\mathrm{p} K_{\mathrm{a}}$ was 9.42. Consistently at physiological pH (7.40), MM exits both neutral state (MM, 99\%) and monoanion state (MM-O6 ${ }^{-}$, 1\%) (Fig. 4) and thus these states are used for further studies in the aqueous solution.

The reactivity of $\mathrm{MM}$ toward $\mathrm{R}^{\bullet}\left(\mathrm{R}=\mathrm{HO}^{\circ}\right.$ and $\left.\mathrm{HOO}^{\circ}\right)$ radicals polar and nonpolar media were assessed by three typical antioxidant mechanisms: formal hydrogen transfer (FHT), single electron transfer (SET), and radical adduct formation (RAF). The processes can be described with the following reactions: ${ }^{\mathbf{2 4 , 4 0}}$
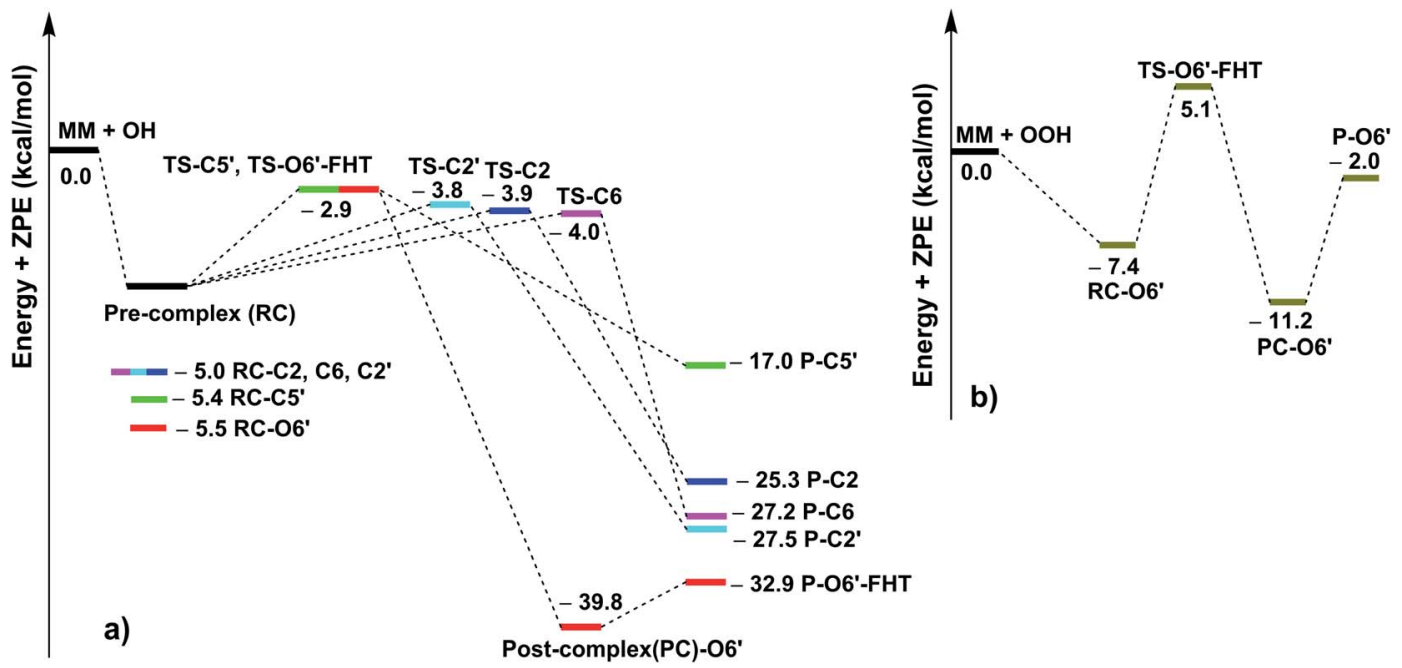

Fig. 2 The PES of reaction according to FHT and RAF mechanisms between the MM and $\mathrm{HO}^{*}$ (a) or $\mathrm{HOO}$ (b) at the typical positions in the gas phase. 


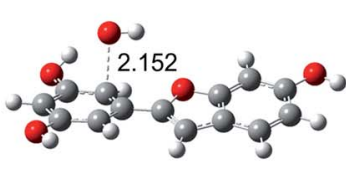

TS-MM-C2-OH-RAF

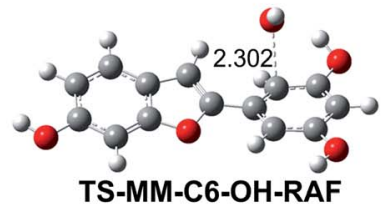

TS-MM-C6-OH-RAF

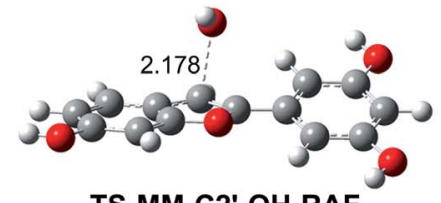

TS-MM-C2'-OH-RAF
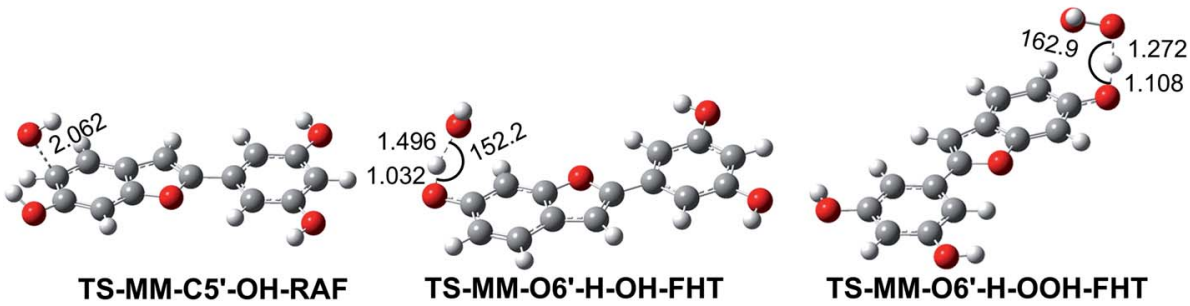

TS-MM-O6'-H-OOH-FHT

Fig. 3 Optimized geometries of the typical transition states according to FHT and RAF mechanisms between the $\mathrm{MM}^{\mathrm{N}}$ and $\mathrm{HO} / \mathrm{HOO}^{\circ}$ radicals in the gas phase.<smiles>Oc1cc(O)cc(-c2cc3ccc(O)cc3o2)c1</smiles>
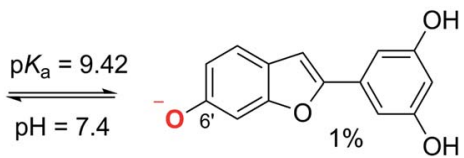

Fig. 4 The deprotonation of MM.

$$
\begin{aligned}
& \mathrm{MM}+\mathrm{R}^{\bullet} \rightarrow \mathrm{MM}^{+} \cdot \mathrm{R}^{-} \quad(\mathrm{SET}-1) \\
& \mathrm{MM}-\mathrm{O}^{\prime-}+\mathrm{R}^{\cdot} \rightarrow \mathrm{MM}-\mathrm{O}^{\prime}{ }^{\bullet}+\mathrm{R}^{-} \quad(\mathrm{SET}-2) \\
& \mathrm{MM}+\mathrm{R}^{\bullet} \rightarrow \mathrm{MM}^{\bullet}+\mathrm{RH} \quad(\mathrm{FHT}) \\
& \mathrm{MM}+\mathrm{R}^{\bullet} \rightarrow \mathrm{MM}-\mathrm{R}^{\cdot} \quad(\mathrm{RAF})
\end{aligned}
$$

where $\mathrm{R}^{\cdot}=\mathrm{HO}^{\bullet}, \mathrm{HOO}^{\circ}$

3.2.2. Kinetic study. Kinetics of the $\mathrm{HO}^{*}$ and $\mathrm{HOO}^{\circ}$ scavenging reactions in the physiological environments was investigated following the (QM-ORSA) protocol, ${ }^{24,30}$ and results are presented in Table 4 . It was found that the $k_{\text {overall }}$ for the $\mathrm{HO}^{\circ}+$ $\mathrm{MM}$ reaction in water and pentyl ethanoate solvents were $2.73 \times$
$10^{10}$ and $1.39 \times 10^{10} \mathrm{M}^{-1} \mathrm{~s}^{-1}$, respectively, whereas those for the $\mathrm{HOO}^{\circ}+\mathrm{MM}^{2}$ reaction were $4.10 \times 10^{7}$ and $3.80 \times 10^{4} \mathrm{M}^{-1} \mathrm{~s}^{-1}$, respectively. The results showed that the $\mathrm{HO}^{\circ}$ antiradical activity was defined by the RAF mechanism $(\Gamma=92.1 \%$ for the lipid medium and $65.5 \%$ for the aqueous solution). The SET pathway contributed about $29.4 \%$ of the overall rate constant in polar solvent, however this pathway had no contribution in the $\mathrm{HO}^{*}$ radical scavenging of $\mathrm{MM}$ in the nonpolar environment. Compared to typical antioxidants such as melatonin, ${ }^{51}$ ramalin, ${ }^{48}$ indole-3-carbinol ${ }^{23}$ and Trolox $^{30}$ the hydroxyl radical scavenging of $\mathrm{MM}$ is in the range defined by these compounds in both polar and non-polar media.

It is important to notice that the single electron transfer pathway (SET-2) of the anion state $\left(\mathrm{MM}-\mathrm{O6}^{-}{ }^{-}\right)$decided the $\mathrm{HOO}^{\circ}$ radical scavenging in water at $\mathrm{pH} 7.4$ despite of the fact that this state makes up only $1 \%$ of the total concentration under the given conditions. Compared with Trolox $(k(\mathrm{HOO})=$ $1.30 \times 10^{5}$ and $1.30 \times 10^{5} \mathrm{M}^{-1} \mathrm{~s}^{-1}$ in pentyl ethanoate and water, respectively $)^{24}$ the $\mathrm{HOO}^{*}$ radical scavenging activity of MM is slightly lower in lipid medium, however in the polar environment it is much higher (315.4 times) than that of Trolox.

Table 4 Gibbs free energies of activation $\left(\Delta G^{\neq}, \mathrm{kcal} \mathrm{mol}{ }^{-1}\right)$, rate constants $\left(k_{\mathrm{app}}, k_{\mathrm{f}}, \mathrm{M}^{-1} \mathrm{~s}^{-1}\right)$ and branching ratios $(T, \%)$ at $298.15 \mathrm{~K}$, in the $\mathrm{MM}$ oxidation by $\mathrm{HO} / \mathrm{HOO}^{\circ}$ radicals in the studied environments

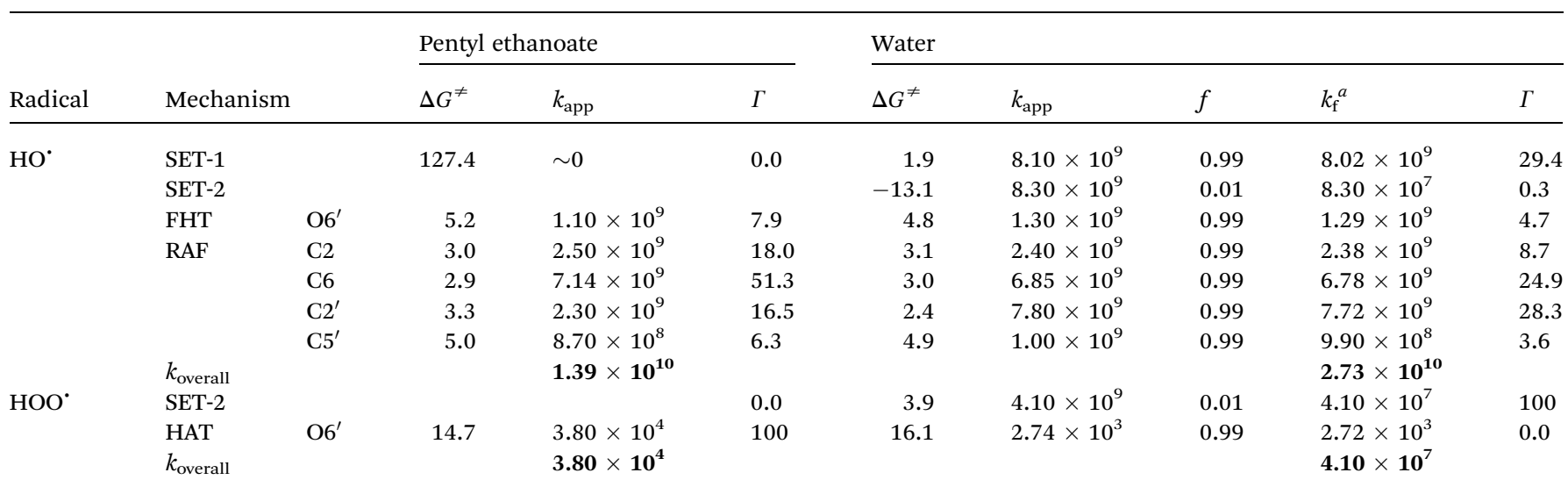

${ }^{a} k_{\mathrm{f}}=f \times k_{\mathrm{app}}$. 
Thus MM is a promising radical scavenger especially in aqueous environment.

\section{Conclusions}

The antioxidant activity of MM was evaluated by thermodynamic and kinetic calculations in the gas phase as well as in physiological environments. It was found that the $k_{\text {overall }}$ for the $\mathrm{HO}^{*}$ radical scavenging in the gas phase was $1.08 \times 10^{11} \mathrm{M}^{-1}$ $\mathrm{s}^{-1}$, whereas that for the HOO ${ }^{\circ}$ antiradical activity was $1.69 \times$ $10^{5} \mathrm{M}^{-1} \mathrm{~s}^{-1}$. In the polar and non-polar media, those for the $\mathrm{HO}^{\circ}+\mathrm{MM}^{-}$reaction were about $10^{10} \mathrm{M}^{-1} \mathrm{~s}^{-1}$, while for the HOO $+\mathrm{MM}$ reaction, $k_{\text {overall }}$ values were $4.10 \times 10^{7}$ and $3.80 \times 10^{4}$ $\mathrm{M}^{-1} \mathrm{~s}^{-1}$, respectively. It is important to notice that the single electron transfer pathway (SET-2) of the anion state $\left(\mathrm{MM}-\mathrm{O6}^{\prime-}\right.$ ) decided the $\mathrm{HOO}^{\circ}$ radical scavenging in water at $\mathrm{pH} 7.4$, while the $\mathrm{HOO}^{*}$ radical scavenging of $\mathrm{MM}$ proceeded via the formal hydrogen transfer mechanism in the lipidic medium. Compared with typical antioxidants such as Trolox, the HOO radical scavenging of $\mathrm{MM}$ is slightly lower in lipid medium but much higher (315.4 times) in water than that of Trolox. Thus $\mathrm{MM}$ is a promising radical scavenger in aqueous physiological environments.

\section{Conflicts of interest}

There are no conflicts to declare.

\section{Acknowledgements}

The research is funded by Vietnam National Foundation for Science and Technology Development (NAFOSTED) under grant number 104.06-2018.308.

\section{References}

1 R. Naik, D. S. Harmalkar, X. Xu, K. Jang and K. Lee, Eur. J. Med. Chem., 2015, 90, 379-393.

2 Z.-P. Zheng, Y. Xu, C. Qin, S. Zhang, X. Gu, Y. Lin, G. Xie, M. Wang and J. Chen, J. Agric. Food Chem., 2014, 62, 55195527.

3 L.-Q. Wang, Z.-R. Tang, W.-H. Mu, J.-F. Kou and D.-Y. He, J. Asian Nat. Prod. Res., 2013, 15, 1210-1213.

4 Y. J. Kim, M.-J. Sohn and W.-G. Kim, Biol. Pharm. Bull., 2012, 35, 791-795.

5 M. Takasugi, Tetrahedron Lett., 1978, 9, 797-798.

6 M. Takasugi, S. Nagao, T. Masamune, A. Shirata and K. Takahashi, Tetrahedron Lett., 1979, 20, 4675-4678.

7 Z. Yang, Y. Wang, Y. Wang and Y. Zhang, Food Chem., 2012, 131, 617-625.

8 V. Kuete, D. Fozing, W. Kapche, A. Mbaveng, J. Kuiate, B. Ngadjui and B. Abegaz, J. Ethnopharmacol., 2009, 124, 551-555.

9 G. D. Kapche, C. D. Fozing, J. H. Donfack, G. W. Fotso, D. Amadou, A. N. Tchana, M. Bezabih, P. F. Moundipa, B. T. Ngadjui and B. M. Abegaz, Phytochemistry, 2009, 70, 216-221.
10 D. Lee, K. P. Bhat, H. H. Fong, N. R. Farnsworth, J. M. Pezzuto and A. D. Kinghorn, J. Nat. Prod., 2001, 64, 1286-1293.

11 K. A. Mohammed, R. C. Jadulco, T. S. Bugni, M. K. Harper, M. Sturdy and C. M. Ireland, J. Med. Chem., 2008, 51, 1402-1405.

12 H. W. Ryu, B. W. Lee, M. J. Curtis-Long, S. Jung, Y. B. Ryu, W. S. Lee and K. H. Park, J. Agric. Food Chem., 2010, 58, 202-208.

13 J. H. Lee, H. J. Ko, E.-R. Woo, S. K. Lee, B. S. Moon, C. W. Lee, S. Mandava, M. Samala, J. Lee and H. P. Kim, Eur. J. Pharmacol., 2016, 783, 64-72.

14 S. H. Seong, M. T. Ha, B. S. Min, H. A. Jung and J. S. Choi, Life Sci., 2018, 210, 20-28.

15 M. Takasugi, S. Nagao, S. Ueno, T. Masamune, A. Shirata and K. Takahashi, Chem. Lett., 1978, 7, 1239-1240.

16 B. Andallu and N. C. Varadacharyulu, Clin. Chim. Acta, 2003, 338, 3-10.

17 X. Li, H. Xie, R. Zhan and D. Chen, Molecules, 2018, 23, 754. 18 J. Tu, D. Shi, L. Wen, Y. Jiang, Y. Zhao, J. Yang, H. Liu, G. Liu and B. Yang, Food Chem. Toxicol., 2019, 132, 110730.

19 Y.-X. Tan, Y. Yang, T. Zhang, R.-Y. Chen and D.-Q. Yu, Fitoterapia, 2010, 81, 742-746.

20 R. Sharma, A. Sharma, T. Shono, M. Takasugi, A. Shirata, T. Fujimura and H. Machii, Biosci., Biotechnol., Biochem., 2001, 65, 1402-1405.

21 H. Boulebd, Free Radical Res., 2020, 1-10.

22 A. Galano and J. Raúl Alvarez-Idaboy, Int. J. Quantum Chem., 2019, 119, e25665.

23 Q. V. Vo, P. C. Nam, M. Van Bay, N. M. Thong and A. Mechler, RSC Adv., 2019, 9, 42020-42028.

24 Q. V. Vo, N. M. Tam, M. Van Bay, N. M. Thong, T. Le Huyen, N. T. Hoa and A. Mechler, RSC Adv., 2020, 10, 14937-14943.

25 K. U. Ingold and D. A. Pratt, Chem. Rev., 2014, 114, 90229046.

26 E. Martín-Tornero, R. N. M. de Jorge Páscoa, A. EspinosaMansilla, I. D. Martín-Merás and J. A. Lopes, Sci. Rep., 2020, 10, 1-13.

27 C. A. T. Dos Santos, M. Lopo, R. N. Páscoa and J. A. Lopes, Appl. Spectrosc., 2013, 67, 1215-1233.

28 G. D. Kapche, P. Waffo-Teguo, S. Massip, J. Guillon, C. Vitrac, S. Krisa, B. Ngadjui and J.-M. Merillon, Anal. Sci., 2007, 23, x59-x60.

29 J. R. l. Alvarez-Idaboy and A. Galano, J. Phys. Chem. B, 2012, 116, 9316-9325.

30 A. Galano and J. R. Alvarez-Idaboy, J. Comput. Chem., 2013, 34, 2430-2445.

31 Q. V. Vo, M. V. Bay, P. C. Nam and A. Mechler, J. Phys. Chem. $B, 2019,123,7777-7784$.

32 M. Carreon-Gonzalez, A. Vivier-Bunge and J. R. AlvarezIdaboy, J. Comput. Chem., 2019, 40, 2103-2110.

33 E. Dzib, J. L. Cabellos, F. Ortíz-Chi, S. Pan, A. Galano and G. Merino, Int. J. Quantum Chem., 2019, 119, e25686.

34 E. Dzib, J. L. Cabellos, F. Ortiz-Chi, S. Pan, A. Galano and G. Merino, Eyringpy 1.0.2, Cinvestav, Mérida, Yucatán, 2018.

35 M. G. Evans and M. Polanyi, Trans. Faraday Soc., 1935, 31, 875-894. 
36 H. Eyring, J. Chem. Phys., 1935, 3, 107-115.

37 D. G. Truhlar, W. L. Hase and J. T. Hynes, J. Phys. Chem., 1983, 87, 2664-2682.

38 T. Furuncuoglu, I. Ugur, I. Degirmenci and V. Aviyente, Macromolecules, 2010, 43, 1823-1835.

39 E. Vélez, J. Quijano, R. Notario, E. Pabón, J. Murillo, J. Leal, E. Zapata and G. Alarcón, J. Phys. Org. Chem., 2009, 22, 971977.

40 H. Boulebd, A. Mechler, N. T. Hoa and Q. Van Vo, New J. Chem., 2020, 44, 9863-9869.

41 E. Pollak and P. Pechukas, J. Am. Chem. Soc., 1978, 100, 2984-2991.

42 A. Fernández-Ramos, B. A. Ellingson, R. Meana-Pañeda, J. M. Marques and D. G. Truhlar, Theor. Chem. Acc., 2007, 118, 813-826.

43 C. Eckart, Phys. Rev., 1930, 35, 1303.

44 M. J. Frisch, G. W. Trucks, H. B. Schlegel, G. E. Scuseria, M. A. Robb, J. R. Cheeseman, G. Scalmani, V. Barone, B. Mennucci, G. A. Petersson, H. Nakatsuji, M. Caricato, X. Li, H. P. Hratchian, A. F. Izmaylov, J. Bloino, G. Zheng, J. L. Sonnenberg, M. Hada, M. Ehara, K. Toyota, R. Fukuda, J. Hasegawa, M. Ishida, T. Nakajima, Y. Honda, O. Kitao, H. Nakai, T. Vreven, J. A. Montgomery, J. E. Peralta, F. Ogliaro, M. Bearpark, J. J. Heyd, E. Brothers, K. N. Kudin, V. N. Staroverov, R. Kobayashi, J. Normand, K. Raghavachari, A. Rendell, J. C. Burant,
S. S. Iyengar, J. Tomasi, M. Cossi, N. Rega, J. M. Millam, M. Klene, J. E. Knox, J. B. Cross, V. Bakken, C. Adamo, J. aramillo, R. Gomperts, R. E. Stratmann, O. Yazyev, A. J. Austin, R. Cammi, C. Pomelli, J. W. Ochterski, R. L. Martin, K. Morokuma, V. G. Zakrzewski, G. A. Voth, P. Salvador, J. J. Dannenberg, S. Dapprich, A. D. Daniels, Ö. Farkas, J. B. Foresman, J. V. Ortiz, J. Cioslowski and D. J. Fox, Gaussian 09, Revision E.01, Gaussian, Inc., Wallingford, CT, 2009.

45 A. Galano and J. R. Alvarez-Idaboy, J. Comput. Chem., 2014, 35, 2019-2026.

46 Y. Zhao and D. G. Truhlar, J. Phys. Chem. A, 2008, 112, 10951099.

47 C. Iuga, J. R. Alvarez-Idaboy and A. Vivier-Bunge, J. Phys. Chem. B, 2011, 115, 12234-12246.

48 Q. V. Vo, N. M. Tam, M. Van Bay and A. Mechler, Chem. Phys. Lett., 2020, 739, 137004.

49 Q. V. Vo, M. Van Bay, P. C. Nam and A. Mechler, ACS Omega, 2019, 4, 19375-19381.

50 A. Galano, A. Pérez-González, R. Castañeda-Arriaga, L. Muñoz-Rugeles, G. Mendoza-Sarmiento, A. RomeroSilva, A. Ibarra-Escutia, A. M. Rebollar-Zepeda, J. R. LeónCarmona and M. A. Hernández-Olivares, J. Chem. Inf. Model., 2016, 56, 1714-1724.

51 A. Galano, Phys. Chem. Chem. Phys., 2011, 13, 7178-7188. 